\title{
Target Social Media Presence and Its Effects on Acquirers' Decision
}

\author{
Nivo Ravaonorohanta ${ }^{1} \&$ Mohammad Refakar ${ }^{1}$ \\ ${ }^{1}$ Business School, University of Sherbrooke, Sherbrooke, Canada \\ Correspondence: Mohammad Refakar, Business School, University of Sherbrooke, Sherbrooke, Canada, QC, \\ J1K 2R1, Canada. Tel: 1-819-821-8000. E-mail: Mohammad.Refakar@USherbrooke.ca
}

Received: November 20, 2020

Accepted: December 9, 2020

Online Published: January 5, 2021

doi:10.5539/ijef.v13n2p1

URL: https://doi.org/10.5539/ijef.v13n2p1

\begin{abstract}
Our objective is to determine whether firms' presence on social media improves the decision-making process in mergers and acquisitions (M\&As), and thus the quality and performance of the transaction. Based on a sample of 309 domestic mergers carried out by Canadian companies between 2012 and 2016, the empirical evidence strongly supports our hypothesis as we find that the active presence of target firms on social media enhances the likelihood of M\&A completion. In addition, M\&As carried out by firms active on social media are also more likely to create value. These findings suggest that information posted on social media helps firms identify the best partnerships, i.e., those target firms with which the acquiring firms will be able to work in synergy.
\end{abstract}

Keywords: information asymmetry, social media, Twitter, merger and acquisition, quality of the transaction

JEL: G34, G14, D82, D83.

\section{Introduction}

A number of studies have found that mergers and acquisitions (M\&As) destroy value more often than they create it (Agrawal, Jaffe, \& Mandelker, 1992; Rau \& Vermaelen, 1998). In the short term, the abnormal returns of the acquiring firm have been found to be around zero, or even negative (Bradley, Desai, \& Kim, 1988; Cai \& Vijh, 2007; Alexandridis, Fuller, Terhaar, \& Travlos, 2013). An integrated analysis of performance measures over the short- and long-term shows that M\&As decrease wealth for shareholders of the acquirer and that the decline in returns is permanent (Cai \& Sevilir, 2012; Loughran \& Vijh, 1997; Oler, Harrison, \& Allen, 2008). A recent study by Alexandridis, Antypas, and Travlos (2017) found that M\&As completed after 2009 have created more value than those completed earlier. Nonetheless, close to $50 \%$ of M\&As continue to lose money for shareholders, with losses of up to US\$1 billion per transaction.

The development of technology and easy access to the Internet have dramatically transformed the way we communicate, in both our social lives and the business community. In recent years, social media, which include various platforms such as YouTube, Facebook, LinkedIn, Vimeo and Twitter, have opened up additional communication channels for firms, creating unprecedented opportunities for interaction between them and their stakeholders. Communication is easy, fast and inexpensive. In the US, for example, the Securities and Exchange Commission (SEC) in April 2013 approved firms' use of social media to communicate any non-confidential information as long as investors are alerted that the firm will be using social media to communicate with them (SEC, 2013). Overall, recent research indicates that social media help improve firms' information environments. To what extent has better access to information through social media improved the performance of M\&As? This article explores the contribution of social media as a supplementary information channel to the quality of corporate investments, more specifically in the context of mergers and acquisitions.

Our study contributes to the literature on how social media in particular, and new networking platforms in general, can impact market efficiency and corporate performance (Zhang, 2015; Blankespoor, 2018; Alexander \& Gentry, 2014; Cade, 2018; Yu, Duan, \& Cao, 2013; Nisar, Prabhakar, \& Strakova, 2019; Parveen, Jaafar, \& Ainin, 2015; Du \& Jiang, 2015; Kane, 2017; Tajudeen, Jaafar, \& Ainin, 2018). It analyzes the benefits and advantages that use of social media can offer firms. This study could open up new perspectives to further understanding of the attraction of social media for firms and the risks entailed in using them.

To our knowledge, this paper and that of Mazboudi and Khalil (2017) are among the first to examine the appeal of social media in an M\&A context. Contrary to these authors, we look beyond the use of social media for simply announcing transactions and examine all the information participating firms post. We also note how the 
ongoing information this new channel provides affects the quality of M\&As. Our analysis addresses various aspects of the quality of M\&As, including their outcome (completion or non-completion), the level of uncertainty involved, the financial returns, and the negotiation period. This study also provides a portrait of the use of social media by Canadian firms listed on an active market.

The paper proceeds as follows. The next section defines the role information plays in the success of M\&As. We then review the literature on social media and develop our research hypotheses. Section three describes our research methodology, while section four sets out and interprets our results. The final section summarizes the study's key findings and their implications and suggests avenues for future research.

\subsection{The Information Environment and M\&A Performance}

Most studies have found M\&A performance less than encouraging. In fact, M\&As appear to destroy value more often than they create it (Alexandridis et al., 2013; Cai \& Vijh, 2007; André et al., 2004; Rau \& Vermaelen, 1998; Agrawal et al., 1992; Bradley et al., 1988). Moreover, An integrated analysis of performance measures over the short- and long-term shows that M\&As decrease wealth for shareholders of the acquirer and that the decline in returns is permanent (Cai \& Sevilir, 2012; Oler et al., 2008; Loughran \& Vijh, 1997). A number of authors consider this value destruction to be linked to excessive premium paid to target firms with which the acquiring firms have little chance of achieving synergies (Hayward, 2007; Harford, Humphery-Jenner, \& Powell, 2012; Claxton, Owen, \& Sadler-Smith, 2013; Zollo \& Meier, 2008). Setting CEO hubris (Roll, 1986) aside, the over-evaluation of synergy potentials appears to indicate an ambiguous information environment that prevents the acquirer from identifying the target it would be profitable to acquire. This situation raises several interesting questions. To what extent does better access to information mitigates the value destruction caused by M\&As? What is the economic impact of firms' growing interest in social media in an M\&A context?

Close to half of American businesses have a Twitter account (Zhou, Lei, Wang, Fan, \& Wang, 2015). Social media have become an information and promotion channel that enables businesses to reach a wide range of users (Kaplan, 2011). The substance and form of the financial information can be adapted to the needs of readers who are not necessarily as sophisticated as the usual recipients of more formal communications. Social media can therefore be powerful voluntary communication tools to reduce information asymmetry between the market and the firm. Twitter and Facebook are the most commonly used social media platforms. However, according to Barnes, Lescault, and Wright (2013), Twitter has the highest adoption rate among professional users prefer. We thus focus on the use of Twitter in an M\&A context.

The literature on the effects of information asymmetry between participating firms on M\&A performance are mixed. Some authors did not find information asymmetry to be detrimental to M\&A performance. Li and Tong (2018) indicate a positive link between uncertainty of information about the target firm and the wealth of the acquirer's shareholders. Other recent research has produced similar results. For instance, Adra and Barbopoulos (2019) and Borochin, Ghosh, and Huang (2019) show that the performance of the acquiring firm declines as the quality of the information environment improves. These findings support those of Chatterjee, John, and Yan (2012), who demonstrate that the overall synergy in M\&As positively correlates with diverging opinions on the value of the target firm. It could thus be argued that an ambiguous information environment would to a certain extent be advantageous to acquiring firms. However, in this context, the gain essentially derives from the under-evaluation of the target at the time of the acquisition and not necessarily from a better match between the two firms. However, this gain is not genuine value creation. The acquirer may have higher returns at the time of acquisition, but these high returns are temporary. According to the theory of market efficiency, the market will adjust its expectations as new information about the transaction surfaces. If there is no synergy, the higher returns will soon be reversed. Not only paying a high acquisition price will damage the acquiring firm's value, but it will also undermine its long-term performance. Ismail (2011) determined that value destruction will continue up to three years after the M\&A and could even endanger the company's survival.

In contrast, another stream of literature highlights he benefits of a transparent information environment and examines various mechanisms that can mitigate information asymmetry thus weakening the M\&As' bad performance (Dutordoir, Roosenboom, \& Vasconcelos, 2014; Siougle, Spyrou, \& Tsekrekos, 2014; Kimbrough $\&$ Louis, 2011). Based on agency theory, these studies show that demand for voluntary disclosures comes from the market, which rewards businesses committed to promoting transparency. Siougle et al. (2014) show that holding conference calls meetings around the date of the M\&A is associated with a significant reduction in analysts' forecasting errors. These calls also significantly reduce market overreaction (positive or negative) around the date of the transaction announcement. Dutordoir et al. (2014) obtained similar findings, reporting that the voluntary communication of information on synergy is tied to an increase in returns of $5 \%$ for the acquiring 
firm. In other words, performance would have been reduced by $5 \%$ if the firms had not voluntarily shared information on synergies. According to Kimbrough and Louis (2011), voluntary communications are not only linked to better performance, but also eliminate the possibility that the returns would subsequently be reversed. Voluntary communications from firms participating in M\&As thus appear to provide the market with relevant information. The higher returns associated with these communications are not an anomaly that will rapidly adjust but are based on synergies that are the source of sustainable financial benefits.

\subsection{Impact of Firms' Presence on Social Media}

Social media offer a number of benefits to companies. Unlike traditional means of disclosure (press releases, conference calls, presentations, social and environmental reports, etc.), they allow organizations to directly control the information they disseminate to stakeholders and to analysts. As Alexander and Gentry (2014) and Dorminey, Dull, and Schaupp (2015) point out, companies use social media to communicate information in more flexible formats than those required for mandatory disclosures. Social media are unique because of the ease with which users can relay, receive/send messages and request comments. They also offer firms a cheaper way to reach a wide range of users in real time.

According to Paniagua and Sapena (2014), the presence of organizations on social media is linked to improved financial performance. The number of followers on social media has a positive impact on firms' share prices, but only after the firm has attracted a certain number of followers. Akmese, Aras, and Akmese (2016) obtained similar results when analyzing various financial performance indicators, showing that the average net profits, the return on equity and the price/earnings ratio of firms that have a social media presence are comparatively higher than those that do not. Blankespoor, Miller, and White (2014) see the communication of news that firms usually disseminate in the press on social media as reducing the bid-ask spread. The positive correlation noted between the volume of communications on social media and market liquidity also reflects an improvement in the quality of the information environment and the mitigation of information asymmetry. This link seems to be particularly strong for firms with low visibility that thus receive little attention from the traditional media over which they have no control.

The only paper which investigates the link between the presence on Twitter and the M\&A performance is Mazboudi and Khalils (2017). They find that acquirers attenuate the anticipated negative market reaction by announcing the acquisition on Twitter. Their findings confirm the role Twitter plays in reducing information asymmetry and show that Twitter acquisition announcement is positively related to cumulative abnormal returns (CARs). However, they analyze isolated disclosures and only consider the acquisition announcement on Twitter. They do not analyze the long-term presence of the company on Twitter on which companies could disseminate relevant news about the company.

What seems remarkable about Paniagua and Sapena (2014) is the mechanism mitigating information asymmetry. Unlike authors analyzing the relevance of isolated disclosures and in specific contexts (Siougle et al., 2014; Mazboudi \& Khalil, 2017), Paniagua and Sapena (2014) consider the communication platform as a whole, taking into account the diversity and strength of the relationships between the firm and the market. Higher returns stem from the overall improvement of the firm's information environment thanks to its proximity to its market and interactive exchanges with a sufficient number of followers. The number of followers implies a body of information that grows in pace with the interactive exchanges between the firm and the market.

Research indicates that value destruction from M\&As is tied to the acquisition of target firms with which the acquirers have little likelihood of achieving synergies and the payment of a high premium because the potential synergy has been overestimated (Hayward, 2007; Harford et al., 2012; Claxton et al., 2013; Zollo \& Singh, 2004; Díaz et al., 2009). Overestimating synergies and poor target selection are signs of information asymmetry. The lack of information prevents the acquirer from identifying a potentially relevant target that can create value for the acquirer. Therefore, the existence of information asymmetry makes it difficult for the acquirer assess the synergy potential with the target. To decrease this information asymmetry, firms chose to voluntarily disclose information on social media. The flexibility of social media enables companies to discuss issues other than those covered by mandatory disclosure and regulatory requirements. According to Parveen et al. (2015), firms use social media to launch products, post ads, and conduct market studies and customer/client satisfaction analyses. Firms also use social media to manage their reputations and public impressions in crisis situations (Gruber, Smerek, Thomas-Hunt, \& James, 2015). The information firms voluntarily disclose on social media can be particularly rich and can improve the transparency of the company in question. Improving the quality of its information environment can help an acquiring firm identify and acquire a target firm that has potential synergies. Therefor, there will be a better match between acquiring and target firms, thereby increasing the likelihood that 
the transaction would be completed. We thus submit the following hypothesis:

\section{$H_{1}$ : The presence of the target firm on Twitter increases the probability of the transaction completion.}

Studies on M\&As indicate that the negotiation period (i.e., the time from when the transaction is first publicly announced to its completion) increases with uncertainty. The bidding war (Shim, 2011; Shenoy, 2012) and the target firm's resistance (Bange \& Mazzeo, 2004; Harford, 2003) are factors that interact with uncertainty to prolong the negotiation period and raise the acquisition cost to the detriment of the acquirer's shareholders. The active presence of target firms on social media could shorten the negotiation period because the acquirer can benefit from the potential of social media to anticipate and respond to the target's expectations. Our second hypothesis thus concerns the negotiation period.

\section{$\mathrm{H}_{2}$ : The presence of target firms on Twitter reduces the negotiation period.}

Voluntary disclosures appear to be positively perceived by the market (Dutordoir et al., 2014; Mazboudi \& Khalil, 2017). They also significantly diminish market overreaction to the transaction announcement (Siougle et al., 2014). According to Dutordoir et al. (2014) and Mazboudi and Khalil (2017), voluntary disclosures play a significant role in diminishing negative market reactions. In an M\&A context, firms' disclosure mechanisms provide the market with additional information that improves the accuracy of the evaluation of the merits of the transaction and cash flow expectations. Reducing information asymmetry should improve target selection and more successfully align the resources of the participating firms, which in turn would enhance value creation. Based on the above, we suggest the following hypothesis:

\section{$H_{3}$ : The presence of target firms on Twitter is associated with positive CARs.}

We include a set of control variables that could affect the acquiring firm performance. All of our control variables have been taken from similar previous studies. We first control for the characteristics of the transaction including transaction value, target previously held common shares, method of payment, bid premium, and number of financial or legal advisors (Grinstein \& Hribar, 2004; Alexandridis et al., 2013; Betton, Eckbo, Thorburn, \& Eckbo, 2007; Alexandridis et al., 2013). Transaction value represents the total value of the acquisition as reported by SDC Platinum. Empirical evidence suggests that transaction size heightens integration complexity and leads to smaller abnormal returns (Gorton, Kahl, \& Rosen, 2009). The previously held common shares is the percentage of common shares of the target firm held by the acquiring firm before the announcement date. According to Ahern (2012), an acquiring firm with a greater percentage of target common shares before the announcement has a stronger bargaining position leading to higher M\&A performance. The method of payment distinguishes between pure cash offers on the one hand and all other offers on the other. We then define the method of payment as being equal to 1 if payment is made solely in terms of cash and 0 otherwise. Previous research tends to show that acquirers are valued more favorably when paying with cash (Goel \& Thakor, 2010; Ismail, 2011). The bid premium is the ratio of the last price offered by the acquiring firm to the target stock price four weeks price prior to the first M\&A announcement date as reported by SDC Platinum. The number of financial or legal advisors is the number of legal or financial advisors to acquiring firm as reported by SDC Platinum. Availability of sophisticated financial and legal advisors is expected to improve the probability of completion and the M\&A return (Goel \& Thakor, 2010; Povel \& Singh, 2006).

A range of acquiring firm characteristics control variables are also constructed based on prior studies including management quality, leverage, and governance (Cai \& Sevilir, 2012, Martynova \& Renneboog, 2009). Following Berkovitch and Narayanan (1993), Shih and Hsu (2009), we took the Tobin's Q as a proxy for the quality of the acquiring firm management. We expected the Tobin's $Q$ to be positively related to the acquiring firm return. Leverage is the ratio of total debt to total assets. Following the disciplining role of debt, acquiring firms with higher leverage earn higher M\&A announcement returns (Field \& Mkrtchyan, 2017). To control for the governance quality, we use board size, board independence and CEO duality. Board size is the number of directors on the Board of directors. Board independence is the percentage of directors who are independent. Large board and higher proportion on independent directors are expected to enhance M\&A quality and performance (Badru, Ahmad-Zaluki, \& Wan-Hussin, 2019; Usman, Zhang, Farooq, Makki, \& Dong, 2018). CEO duality is a dummy variable indicating whether the CEO is also the board chair.

\section{Data Sample and Descriptive Statistics}

\subsection{Sample Selection and Data Source}

We use the Securities Data Corporation (SDC) Platinum Database to identify deals by Canadian public companies between January 1, 2012 and December 31, 2016. We select M\&As where both acquirer and target are headquartered in Canada and both are publicly traded. Between January 1, 2012 and December 31, 2016, 398 
M\&As amongst Canadian public companies were announced. We eliminate transactions whose outcome remains unknown (38 transactions) and those for which information about the characteristics of the transaction is not available on SDC Platinum (53 transactions). For each deal, we hand collecte target presence on Twitter, the number of target Twitter account's followers and its number of tweets, from their Twitter account. Board characteristics are retrieved from BoardEx, financial information is downloaded from Compustat and Capital IQ. Our final sample comprises of 297 transactions of which 238 are completed and 59 are non-completed.

We consider that a firm is on Twitter if it has Twitter account at least 12 months prior to the M\&A announcement. We visit each target firm's profile page on Twitter to collect the number of tweets during 12 months prior to the M\&A. The numbers of following and followers are collected at the transaction date.

\subsection{Descriptive Statistics}

Table 1 provides descriptive statistics for the total sample of 297 M\&A transactions. The mean, median and standard deviation for each variable are illustrated. The sample is divided in to completed transactions and non-completed M\&A transactions. Table 1 shows that 59\% of targets have a Twitter account at least 12 months before the transaction date. The targets have an average of 35,870 followers. They also have tweeted on average 346 times and they follow on average 573 other Twitter accounts. On average, they have a board size of 7 , percentage of leverage of $50 \%$ and Tobin $Q$ of 2.

$60 \%$ of targets of the completed transactions are active on Twitter comparing to $57 \%$ of targets of non-completed transactions. Completed targets have on average 26379 followers and non-completed targets have on average 74155 followers. Non-completed targets on average tweet only 182 times comparing to 387 times for completed targets. Completed transactions have an average target board size of 7, percentage of leverage of 52\% and Tobin Q of 2.1. Non-completed transactions, however, have in average 5 people on the board, have a $47 \%$ of leverage and Tobin Q of 1.6.

Table 1. Descriptive statistics

\begin{tabular}{rccccccccc}
\hline & \multicolumn{3}{c}{$\begin{array}{c}\text { Completed } \\
\text { 238 observations }\end{array}$} & \multicolumn{3}{c}{$\begin{array}{c}\text { Non-Completed } \\
\text { 59 observations }\end{array}$} & \multicolumn{3}{c}{ Total Sample } \\
& Mean & Median & Std Dev. & Mean & Median & Std Dev. & Mean & Median & Std Dev. \\
\cline { 2 - 9 }$y$ Board Independence & 76.126 & 83.330 & 22.661 & 74.984 & 80 & 24.408 & 75.899 & 83.330 & 16.775 \\
Board size & 7.185 & 7.000 & 3.153 & 5.39 & 5 & 3.343 & 6.828 & 7.000 & 3.265 \\
CEO Duality & 0.2 .73 & 0.000 & 0.446 & 0.322 & 0 & 0.471 & 0.283 & 0.000 & 0.451 \\
\% weeks) & 2.207 & 0.201 & 6.085 & 96.124 & 50 & 188.578 & 20.864 & 0.304 & 91.688 \\
\% Premium announced (4 & & 8 & 261.63 & 47.745 & 6 & 65.047 & 50.46 & 9 & 235.877 \\
Tobin Q & 2.165 & 0.966 & 4.895 & 1.675 & 0.68 & 3.251 & 2.068 & 0.966 & 4.895 \\
Target following & 619.924 & 45.000 & 2980.723 & 386.814 & 4 & 1175.327 & 573.616 & 25.000 & 2719.031 \\
Target follower & 26379.752 & 140.000 & 350202.427 & 74155.475 & 17 & 556312.93 & 35870.552 & 136.000 & 399002.492 \\
\% Target on Twitter & 60.1 & 100 & 49.1 & 57.62 & 100 & 49.83 & 59.6 & 100 & 49.2 \\
Target Tweets & 387.693 & 8.000 & 1703.702 & 182.153 & 2 & 762.339 & 346.862 & 6.000 & 1563.542 \\
Transaction value M\$ & 262.291 & 22.509 & 966.675 & 190.06 & 9.97 & 682.002 & 247.942 & 18.645 & 916.610 \\
Advisors & 12.681 & 9.000 & 16.003 & & & & & & \\
CAR & -0.012 & -0.010 & 0.176 & & & & & & \\
CAR (positive / negative) & 0.416 & 0.000 & 0.494 & & & & & &
\end{tabular}

Table 2 illustrates the distribution of acquisitions by industry. The M\&A deals in our sample occur in different industries. The total value of the M\&A transaction is more than 73 billion dollars with he completed deals valuing more than 62 billion dollars. The mining sector is the most active by comprising $57 \%$ of our sample with a value of 21 billion dollars, followed by the energy sector which accounts for $20 \%$ of the sample with a value of 15 billion dollars. Together they account for more than $75 \%$ of our sample in number. However, the mining sector comprises about $30 \%$ of transaction value of our sample, followed by the food distribution sector which accounts for $25 \%$ of the total transaction value. In the sample, $69 \%$ of completed transactions targets in mining have a Twitter account comparing to $73 \%$ for non-completed. $70 \%$ of targets of the mining sector transactions have an active Twitter account whereas $34 \%$ for the energy sector and $45 \%$ for food distributing sector. At the global level, since 2011, 50\% of M\&As announced have been mega-transactions of over US $\$ 5$ billion. Canada is holding its own with three mega-transactions of over US\$5 billion, accounting for $34 \%$ of the total value of the 
transactions in our sample, the largest being the acquisition of Shoppers Drug Mart by Loblaws for US $\$ 11.8$ billion.

Table 2. M\&As by industry sector

\begin{tabular}{|c|c|c|c|c|c|c|c|c|c|c|c|c|c|c|}
\hline \multirow[b]{3}{*}{ Sector } & \multicolumn{4}{|c|}{ Completed } & \multicolumn{4}{|c|}{ Non-completed } & \multicolumn{6}{|c|}{ TOTAL } \\
\hline & \multirow[t]{2}{*}{$\mathrm{Nb}$} & \multirow{2}{*}{$\begin{array}{l}\text { Value } \\
\text { M\$ }\end{array}$} & \multicolumn{2}{|c|}{ On Twitter } & \multirow[t]{2}{*}{$\mathrm{Nb}$} & \multirow{2}{*}{$\begin{array}{l}\text { Value } \\
\text { M\$ }\end{array}$} & \multicolumn{2}{|c|}{ On Twitter } & \multirow[t]{2}{*}{$\mathrm{Nb}$} & \multirow[t]{2}{*}{$\%$} & \multirow{2}{*}{$\begin{array}{c}\text { Value } \\
\text { M\$ }\end{array}$} & \multirow[t]{2}{*}{$\%$} & \multicolumn{2}{|c|}{ On Twitter } \\
\hline & & & $\mathrm{Nb}$ & $\%$ & & & $\mathrm{Nb}$ & $\%$ & & & & & $\mathrm{Nb}$ & $\%$ \\
\hline Mining & 137 & 16464.94 & 95 & 69.34 & 34 & 4886.89 & 25 & 73.53 & 171 & 57.57 & 21351.82 & 29.00 & 120 & 70.18 \\
\hline Energy & 53 & 14488.73 & 19 & 35.85 & 8 & 1305.57 & 2 & 25.00 & 61 & 20.53 & 15794.29 & 21.45 & 21 & 34.43 \\
\hline Food distribution & 23 & 17615.98 & 11 & 47.83 & 8 & 432.39 & 3 & 37.50 & 31 & 10.43 & 18048.37 & 24.51 & 14 & 45.16 \\
\hline Brokerage. insurance & 3 & 168.60 & 2 & 66.67 & 2 & 4373.02 & 2 & 100.00 & 5 & 1.68 & 4541.62 & 6.17 & 4 & 80.00 \\
\hline Communications & 7 & 11133.13 & 7 & 100.00 & 1 & 1.10 & 1 & 100.00 & 8 & 2.69 & 11134.22 & 15.12 & 8 & 100.00 \\
\hline Other & 15 & 2553.80 & 9 & 60.00 & 6 & 214.60 & 1 & 16.67 & 21 & 7.07 & 2768.39 & 3.76 & 10 & 47.62 \\
\hline Total & 238 & 62425.17 & 143 & 60.08 & 59 & 11213.56 & 34 & 57.63 & 297 & & 73638.73 & & 178 & 59.60 \\
\hline
\end{tabular}

\section{Results}

\subsection{Determinants of the Probability of Completion}

In this section, we analyse the determinants of the probability of completion of a M\&A transaction using the following Logit model:

$$
\begin{gathered}
\text { Probability of completion }=\delta_{o}+\delta_{1} \text { Target on Twitter }+\delta_{2} \text { Target followers }+\delta_{3} \text { Target tweets } \\
+\delta_{4} \text { Transaction value }+\delta_{5} \text { Percentage held }+\delta_{6} \text { premium }+\delta_{7} \text { Tobin's } q+\delta_{8} \text { Leverage } \\
+\delta_{9} B D \text { Independence }+\delta_{10} \text { BD size }+\delta_{11} \text { CEO Duality }+\varepsilon
\end{gathered}
$$

where the probability of completion is a dummy variable that equals one if the M\&A deal is completed. We expect that M\&As that involve target firms which are present on Twitter will be positively associated with high probability of completion. All the other variables are defined in Appendix 1.

We argue that presence of the target on Twitter will decrease the information asymmetry between the target and acquirers. Information posted on Twitter helps the acquiring firm to carefully select its target; in other words, to clearly identify the company that has the skills and resources that it is specifically seeking in its strategic plan. The result is a better match between the acquiring and target firms that increases the probability of completion of

\begin{tabular}{|c|c|c|c|c|}
\hline & Model 1 & & Model 2 & \\
\hline & Coeff & Sig. & Coeff & Sig. \\
\hline Intercept & 0.352 & & 0,506 & \\
\hline Target followers & 0.000 & $* * *$ & 0,001 & $* *$ \\
\hline Target following & 0.000 & $* *$ & $-0,007$ & $* * *$ \\
\hline Target on Twitter & 0.164 & & 0,079 & \\
\hline Target Tweets & 0.003 & $* * *$ & 0,003 & $* * *$ \\
\hline Premium announced (4 weeks) & -0.194 & $* * *$ & $-0,193$ & $* * *$ \\
\hline Percentage held & 0.028 & $* * *$ & 0,027 & $* * *$ \\
\hline Transaction value & 0.002 & $* *$ & 0,002 & $* *$ \\
\hline Leverage & -0.370 & & 0,462 & \\
\hline Tobins'Q & 0.026 & & 0,052 & \\
\hline Board Independence & & & 0,215 & \\
\hline Board size & & & 3,310 & \\
\hline CEO Duality & & & 0,374 & \\
\hline Observations & 297 & & 297 & \\
\hline $\mathrm{R} 2$ & 0,228 & & 0,233 & \\
\hline
\end{tabular}
the transaction. Table 3 presents the results of the Logit estimation of the equation (1).

Table 3. M\&A probability of completion

The results are very interesting. Both Target Followers and Target Following are statistically significant and have the expected sign. It means that Twitter activity could increase the probability of the completion of mergers and acquisitions. Moreover, Target Tweets is also statistically significant and positive. As the target is more active on Twitter with more tweets and shares more relevant information about the company, and the probability of deal completion increases. Moreover, percentage held before the transaction is also statistically significant and positive meaning that having shares before the transaction helps the acquirers in selecting better targets. 
These findings are consistent with those of prior studies on the usefulness of disclosures and the benefits of a transparent information environment (Leuz \& Verrecchia, 2000; Lambert, Leuz \& Verrecchia, 2007; Siougle et al., 2014; Dutordoir et al., 2014). None of the governance variables are significative. We expect that board independence have a positive effect on the completion of the deals. However, our results indicate a positive and non-significant correlation between the size of the board of directors and the probability the M\&A will be completed. This correlation does not support the results of most earlier research, which found that the number of directors would not necessarily reflect the influence and effectiveness of the board (Carline, Linn, \& Yadav, 2009; Bange \& Mazzeo, 2004; Cai \& Sevilir, 2012). We also observe a positive and significant relationship between the transaction value and the likelihood it will be completed. Our findings are consistent with those of previous studies. Grinstein and Hribar (2004) found that the efforts management makes to conclude the transaction increase with the transaction value, mainly because of the bonus associated with high-value transactions.

These results confirm our expectations about the contribution of social media to the outcome of M\&As. It appears that information posted on Twitter helps the acquiring firm to carefully select its target; in other words, to clearly identify the company that has the skills and resources that it is specifically seeking in its strategic plan. The result is a better match between the acquiring and target firms that promotes the completion of the transaction. These findings are consistent with those of prior studies on the usefulness of disclosures and the benefits of a transparent information environment (Leuz \& Verrecchia, 2000; Lambert et al., 2007; Siougle et al., 2014; Dutordoir et al., 2014).

\subsection{Determinants of the Negotiation Period}

To study the effect of the presence of target firms on Twitter on the negotiation period, we deploy the following multiple linear regression model.

$$
\begin{gathered}
\text { Period }=\delta_{o}+\delta_{1} \text { Target on Twitter }+\delta_{2} \text { Target followers }+\delta_{3} \text { Target following } \\
+\delta_{4} \text { Target tweets }+\delta_{5} \text { Transaction value }+\delta_{6} \text { Percentage held }+\delta_{7} \text { Cash payment }+\delta_{8} \text { premium } \\
+\delta_{9} \text { Tobin's } q+\delta_{10} \text { Leverage }+\delta_{11} \text { BD Independence }+\delta_{12} \text { BD size }+\delta_{13} \text { CEO Duality } \\
+\delta_{14} \text { Advisors }+\varepsilon
\end{gathered}
$$

We expect that M\&As that the presence of participating firms on social media will be associated with a reduced the negotiation period given the reduction in the cost of information.

Table 4. Negotiation period

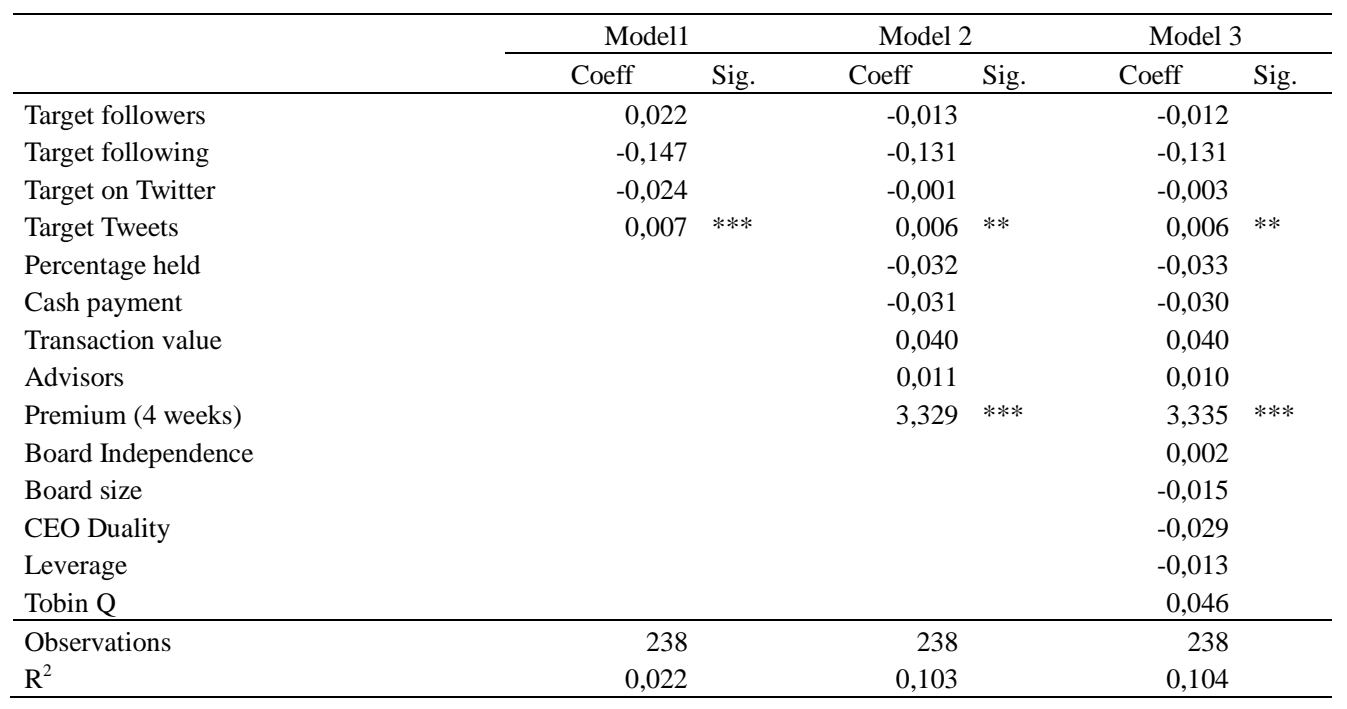

Table 4 presents the results of the analyses focus on the completed transactions and exploring the relationship between the firms' presence on social media and the negotiation period and performance. Our model includes variables from the preceding model as well as variables that are characteristic of the transaction but available only for the completed transactions.

The findings do not support our hypothesis. Most of the Twitter variables are not statistically significant except the number of target tweets which is significant at the $1 \%$ level in model 1 and $5 \%$ in other models. This shows that while presence on Twitter, per se, do not affect the negotiation period, the intensity of Twitter activity (number of tweets) surprisingly, has a positive effect on period. The transaction value and the percentage of 
shares held by the acquiring firm are positively associated with the negotiation period. These results tie in with those of Renneboog and Zhao (2014), who found that a previous connection between the directors of the target firm and the acquiring firm would reduce the negotiation period. The fact that the acquiring firm had an initial investment in the target firm implies a previous connection that puts them in a more advantageous informational position than other unconnected firms.

\subsection{Effects on CARs}

Our last analysis relates to M\&A performance. We examine the association of the presence of target firms on Twitter and the acquiring firm performance after controlling for factors documented in previous literature. We use the cumulative abnormal returns (CARs) to measure the acquirer's performance after M\&As transaction. This measure is widely used in the literature of M\&A (Dutta \& Jog, 2009; Bown \& Warner, 1980, 1985; Elleuch, 2003 Alexandridis et al., 2013; Cai \& Sevilir, 2012; Dutta \& Jog, 2009). To calculate the CARs, we use the historical share prices and the S\&P/TSX Composite Index as a reference for estimating the returns. The abnormal returns, $\mathrm{AR}_{\mathrm{it}}$ of firm $\mathrm{i}$ at time $\mathrm{t}$ are the difference between the returns observed, $\mathrm{R}_{\mathrm{it}}$, and those estimated $\mathrm{E}\left(\mathrm{R}_{\mathrm{it}}\right)$ using the market model. Following Brown and Warner (1985), the daily abnormal returns calculated over a window of 11 days $(-5,+5)$ and then cumulated to obtain $C A R_{i t}$. The procedure is applied for each firm $i$ of the sample, given that each firm has its own announcement date. The formulas used and steps taken to obtain the cumulative returns are presented below.

$$
\begin{gathered}
C A R_{i t}=\sum_{t=1}^{\tau} A R_{i t} \text { where } A R_{i t}=R_{i t}-E\left(R_{i t}\right) \text {, and } E\left(R_{i t}\right)=\alpha_{i}+\beta_{i} R_{m t}+\varepsilon_{i t} \\
\operatorname{pr}(\mathrm{CAR}>0)=\delta_{o}+\delta_{1} \text { Target on Twitter }+\delta_{2} \text { Target followers }+\delta_{3} \text { Target following } \\
+\delta_{4} \text { Target tweets }+\delta_{5} \text { Transaction value }+\delta_{6} \text { Percentage held }+\delta_{7} \text { Cash payment }+\delta_{8} \text { premium } \\
+\delta_{9} \text { Tobin's } q+\delta_{10} \text { Leverage }+\delta_{11} \text { BD Independence }+\delta_{12} \text { BD size } \\
+\delta_{13} \text { CEO Duality }+\delta_{14} \text { Advisors }+\varepsilon
\end{gathered}
$$

CAR $=\delta_{o}+\delta_{1}$ Target on Twitter $+\delta_{2}$ Target followers $+\delta_{3}$ Target following $+\delta_{4}$ Target tweets

$+\delta_{5}$ Transaction value $+\delta_{6}$ Percentage held $+\delta_{7}$ Cash payment $+\delta_{8}$ premium $+\delta_{9}$ Tobin's $q$

$+\delta_{10}$ Leverage $+\delta_{11} B D$ Independence $+\delta_{12} B D$ size $+\delta_{13}$ CEO Duality $+\delta_{14}$ Advisors $+\varepsilon$

$C A R_{i t}$ is the cumulative abnormal returns of the firm i at time t. $A R_{i t}$ in the abnormal return. $R_{i t}$ is the daily stock return of the firm $i$ at time $t . E\left(R_{i t}\right)$ is the expected return given the benchmark portfolio. $R_{m t}$ is the return on a market index for the same period. $\alpha i$ and $\beta i$ are ordinary least squares (OLS) values from the estimation period, 180 days prior to the M\&A announcement. $\varepsilon_{i t}$ is the error term.

We expect that presence of target firm on Twitter will be positively associated with acquirer return. Other studies on M\&A performance directly analyze the effects of their variable of interest on CARs. However, we first examine the probability of positive returns, then by using a linear OLS regression, we analyze the effects of the Twitter variables on the CARs. We use a five days before and five days after the announcement window of the transaction to cumulate abnormal returns (Bradley et al., 1988; Renneboog \& Zhao, 2014).

Table 5. Probability of positive abnormal returns

\begin{tabular}{lcc}
\hline & \multicolumn{2}{c}{ Model1 } \\
\cline { 2 - 3 } & Coeff & Sig. \\
\hline Constant & 0.494 & \\
Target followers & 1.972 & \\
Target following & 1.143 & $* * *$ \\
Target on Twitter & 1.245 & \\
Target Tweets & 0.119 & $* *$ \\
Percentage held & -0.028 & \\
Cash payment & 3.131 & \\
Transaction value & 0.670 & \\
Advisors & 0.071 & $* *$ \\
Premium (4 weeks) & 0.714 & \\
Board Independence & 0.023 & \\
Board size & -0.110 & \\
CEO Duality & 0.539 & \\
Leverage & 0.688 & \\
Tobin Q & 0.348 & \\
\hline Observations & 238 & \\
R2 & 0.219 & \\
\hline
\end{tabular}


Table 5 presents the results of logistics estimates of equation (4). The results are revealing. These results highlight the role an active presence on Twitter plays in improving M\&A performance and support our hypothesis. A M\&A involving a target firm that is active on Twitter is more likely to create than to destroy value. These results complete those obtained Table 3 and indicate that the benefits from a presence on social media extend beyond the likelihood of the transaction being completed. The presence of target on Twitter is positive and statistically significant at $1 \%$ level. This means that presence of the target on Twitter increase the probability of having a positive CARs. Other Twitter variables are not statistically significant, but they all have the expected sign (+). The increase in the probability of value creation is consistent with the mitigation of information asymmetry on which our hypothesis is based. The negative link between the target firm's share volatility and the M\&A's performance confirms the positive impact that social media presence has on information asymmetry and, in turn, on the quality of the transaction.

In terms of governance variables, the proportion of inside directors would increase the likelihood of value creation. Our results are similar to those found in the literature on the importance of the board of directors, more specifically independent directors, in protecting shareholder interests. The effectiveness of independent members lies in their ability to adopt a critical stance and maintain a certain level of skepticism about executives' decisions. Since they do not participate in the firm's internal affairs, it is assumed that they can bring new perspectives to the proposed transaction (Fama \& Jensen, 1983; Harford, 2003; Bange \& Mazzeo, 2004)

Table 6 presents the OLS regression of the determinants of CARs. The results are interesting. All the Twitter variables are statistically significant. Target followers and target following has a negative sign which is not supporting our hypothesis. However, the presence of the target on Twitter and the number of Tweets are positive and statistically significant at $1 \%$ level for the three models. This shows that the more the target is active on Twitter, the less asymmetry exists between the target and the acquirer, and the more synergy is observed following the transaction. This confirms our hypothesis. For the governance variables, the board independence is positive and statistically significant at $1 \%$ level which shows that the board independence has a positive effect on the CARs.

Table 6. Acquiring performance (linear regression)

\begin{tabular}{|c|c|c|c|c|c|c|}
\hline & \multicolumn{2}{|c|}{ Model1 } & \multicolumn{2}{|l|}{ Model 2} & \multicolumn{2}{|l|}{ Model 2} \\
\hline & Coeff & Sig. & Coeff & Sig. & Coeff & Sig. \\
\hline Constant & $-0,069$ & & 0,083 & & $-0,173$ & \\
\hline Target followers & $-0,001$ & $* *$ & $-0,001$ & $* *$ & $-0,001$ & $* *$ \\
\hline Target following & $-0,001$ & $* * *$ & $-0,001$ & $* * *$ & $-0,001$ & $* * *$ \\
\hline Target on Twitter & 0,083 & $* * *$ & 0,083 & $* * *$ & 0,060 & **** \\
\hline Target Tweets & 0,005 & $* * *$ & 0,005 & $* * *$ & 0,004 & $* * *$ \\
\hline Percentage held & & & $-0,077$ & & $-0,073$ & \\
\hline Cash payment & & & 0,083 & & 0,079 & \\
\hline Transaction value & & & $-0,008$ & & $-0,019$ & \\
\hline Advisors & & & 0,003 & & 0,003 & \\
\hline Premium (4 weeks) & & & 0,024 & & 0,012 & \\
\hline Board Independence & & & & & 0,001 & $* * *$ \\
\hline Board size & & & & & $-0,041$ & \\
\hline CEO Duality & & & & & $-0,111$ & \\
\hline Leverage & & & & & $-0,053$ & \\
\hline Tobin Q & & & & & 0,007 & $* * *$ \\
\hline Observations & & & & & 238 & \\
\hline Adjusted R2 & 0,138 & & 0,138 & & 0,191 & \\
\hline
\end{tabular}

\section{Discussion}

In recent years, social media have opened up new communication channels for firms. This study examines the impact of the presence of firms on social media in an M\&A context. Given that many studies on M\&As have largely determined that these transactions destroy the shareholder wealth of the acquiring firms (Agrawal et al., 1992; Rau \& Vermaelen, 1998; Bradley et al., 1988; Cai \& Vijh, 2007; Alexandridis et al., 2013), we based our research on the theory of market efficiency and the role that disclosure plays in the financial market to determine whether the presence of firms on social media helps improve the quality of M\&A transactions and the subsequent returns. This question is particularly relevant since poor target selection and the over-evaluation of synergies are among the factors underlying this value destruction (Hayward, 2007; Harford et al., 2012; Claxton 
et al., 2013; Zollo \& Meier, 2008). These factors signal an information problem that prevents firms from identifying sources of synergy and evaluating the merits of the transaction.

Our results are consistent with the findings of prior research in a number of respects. Our study shows that a transparent information environment is linked to improved performance (e.g., Kothari, Li, \& Short, 2009; Iatridis, 2013). We highlight the important role participating firms' communications play in ensuring the success of the transaction, not only in terms of its completion, but also in terms of its economic benefits (e.g., Siougle et al., 2014; Dutordoir et al., 2014).

Our results open up new avenues for research on the improvement of M\&A performance. Two key findings emerge from our analyses. First, the quality of the M\&A is dependent on the quality of the communications of the participating firms, particularly those of the target firm. Second, social media help improve the quality of organizations' information environment and in turn the performance of their transactions. Thus, social media provide the market with additional information that promotes alignment between firms likely to work in synergy. This constitutes a step forward in the research on factors likely to improve M\&A performance.

Our findings suggest that social media are a relevant communications channel for organizations. As effective and inexpensive communication tools, they provide firms with opportunities to reach a large number of stakeholders worldwide. Firms' presence on social media reflects their ability to disseminate information and their commitment to promoting transparency and creating proximity to the market. Our results show that investors are interested in corporate publications on social media. These media provide a wealth of information that could be used to enhance understanding of a firm's environment in the search for a partnership. Executives of acquiring firms can follow the evolution of public opinion on firms they have targeted and tap directly into debates and discussions on topics of interest to followers. In this respect, Twitter offers real methodological benefits, making it relevant for research involving user opinion surveys. As well, further reflection on the regulations targeting financial information posted on social media could be useful to communications regulatory bodies.

Our research has some limitations. A number of firms' publications on Twitter could not be completely downloaded. It was also impossible to accurately determine the presence on Twitter (number of posts and number of followers) of other firms on the transaction date. In these cases, we used the number of followers and tweets on the date closest to the announcement date. Furthermore, the analyses covered all publications on Twitter irrespective of their content (news about the organization or not) and nature (good or bad news). Since research on disclosure and impression management has found that market reaction depends on the quantity of good or bad news an firm publishes (Clatworthy \& Jones, 2003; Smith \& Taffler, 2000), future research could analyze the relationship between publication content and M\&A performance.

\section{References}

Adra, S., \& Barbopoulos, L. G. (2019). Liquidity and information asymmetry considerations in corporate $\begin{array}{lllll}\text { takeovers. The European Journal of } & \text { Finance, }\end{array}$ https://doi.org/10.1080/1351847X.2018.1543202

Agrawal, A., Jaffe, J. F., \& Mandelker, G. N. (1992). The Post-Merger Performance of Acquiring Firms: A Re-examination of an Anomaly. Journal of Finance, 47(4), 1605-1621. https://doi.org/10.1111/j.1540-6261.1992.tb04674.x

Ahern, K. R. (2012). Bargaining power and industry dependence in mergers. Journal of Financial Economics, 103(3), 530-550. http://dx.doi.org/10.1016/j.jfineco.2011.09.003

Akmese, H., Aras, S., \& Akmese, K. (2016). Financial Performance and Social Media: A Research on Tourism Enterprises Quoted in Istanbul Stock Exchange (BIST). Procedia Economics and Finance, 39, 705-710. https://doi.org/10.1016/S2212-5671(16)30281-7

Alexander, R. M., \& Gentry, J. K. (2014). Using social media to report financial results. Business Horizons, 57(2), 161-167. https://doi.org/10.1016/j.bushor.2013.10.009

Alexandridis, G., Antypas, N., \& Travlos, N. (2017). Value creation from M\&As: New evidence. Journal of Corporate Finance, 45, 632-650. https://doi.org/10.1016/j.jcorpfin.2017.05.010

Alexandridis, G., Fuller, K. P., Terhaar, L., \& Travlos, N. G. (2013). Deal size, acquisition premia and $\begin{array}{lllll}\text { shareholder gains. Journal of Corporate } & \text { Finance, } & \text { 20(0), } & \text { 1-13. }\end{array}$ http://dx.doi.org/10.1016/j.jcorpfin.2012.10.006

Badru, B. O., Ahmad-Zaluki, N. A., \& Wan-Hussin, W. N. (2019). Women on corporate boards and allocation of capital raised through IPOs. Management Decision, 57(3), 547-568. 
https://doi.org/10.1108/MD-11-2017-1121

Bange, M. M., \& Mazzeo, M. A. (2004). Board Composition, Board Effectiveness, and the Observed Form of Takeover Bids. The Review of Financial Studies, 17(4), 1185-1215. https://doi.org/10.1093/rfs/hhh001

Barnes, N. G., Lescault, A. M., \& Wright, S. (2013). Fortune 500 are bullish on social media: Big companies get excited about Google+, Instagram, Foursquare and Pinterest. Retrieved from http://www.umassd.edu/cmr/socialmediaresearch/2013 fortune500/>

Berkovitch, E., \& Narayanan, M. P. (1993). Motives for Takeovers: An Empirical Investigation. The Journal of Financial and Quantitative Analysis, 28(3), 347-362. https://doi.org/10.2307/2331418

Betton, S., Eckbo, B. E., Thorburn, K. S., \& Eckbo, B. E. (2007). Corporate Takeovers. In Handbook of Empirical Corporate Finance (pp. 291-429). Elsevier.

Blankespoor, E. (2018). Firm communication and investor response: A framework and discussion integrating social media. Accounting, Organizations \& Society, 68, 80-87. https://doi.org/10.1016/j.aos.2018.03.009

Blankespoor, E., Miller, G. S., \& White, H. D. (2014). The Role of Dissemination in Market Liquidity: Evidence from Firms' Use of Twitter ${ }^{\mathrm{TM}}$. Accounting Review, 89(1), 79-112. https://doi.org/10.2308/accr-50576

Borochin, P., Ghosh, C., \& Huang, D. (2019). Target information asymmetry and takeover strategy: Insights from a new perspective. European Financial Management, 25(1), 38-79. https://doi.org/10.1111/eufm.12199

Bradley, M., Desai, A., \& Kim, E. H. (1988). Synergistic gains from corporate acquisitions and their division between the stockholders of target and acquiring firms. Journal of Financial Economics, 21(1), 3-40. https://doi.org/10.1016/0304-405x(88)90030-x

Brown, S. J., \& Warner, J. B. (1980). Measuring security price performance. Journal of Financial Economics, 8(3), 205-258. https://doi.org/http://dx.doi.org/10.1016/0304-405X(80)90002-1

Brown, S. J., \& Warner, J. B. (1985). Using daily stock returns: The case of event studies. Journal of Financial Economics, 14(1), 3-31. https://doi.org/10.1016/0304-405X(85)90042-X

Cade, N. L. (2018). Corporate social media: How two-way disclosure channels influence investors. Accounting, Organizations and Society, 68-69, 63-79. https://doi.org/10.1016/j.aos.2018.03.004

Cai, J., \& Vijh, A. M. (2007). Incentive Effects of Stock and Option Holdings of Target and Acquirer CEOs. The Journal of Finance, 62(4), 1891-1933. https://doi.org/10.1111/j.1540-6261.2007.01260.x

Cai, Y., \& Sevilir, M. (2012). Board connections and M\&A transactions. Journal of Financial Economics, 103(2), 327-349. https://doi.org/10.1016/j.jfineco.2011.05.017

Carline, N. F., Linn, S. C., \& Yadav, P. K. (2009). Operating performance changes associated with corporate mergers and the role of corporate governance. Journal of Banking \& Finance, 33(10), 1829-1841. https://doi.org/10.1016/j.jbankfin.2009.03.012

Chatterjee, S., John, K., \& Yan, A. (2012). Takeovers and Divergence of Investor Opinion. The Review of Financial Studies, 25(1), 227-277. https://doi.org/10.1093/rfs/hhr109

Clatworthy, M., \& Jones, M. J. (2003). Financial reporting of good news and bad news: Evidence from accounting narratives. Accounting \& Business Research, 171-185.

Claxton, G., Owen, D., \& Sadler-Smith, E. (2013). Hubris in leadership: A peril of unbridled intuition? Leadership. https://doi.org/10.1177/1742715013511482

Dorminey, J. W., Dull, R. B., \& Schaupp, L. C. (2015). The effect of SEC approval of social media for information dissemination. Research in Accounting Regulation, 27(2), 165-173. https://doi.org/10.1016/j.racreg.2015.09.007

Du, H., \& Jiang, W. (2015). Do Social Media Matter? Initial Empirical Evidence. Journal of Information Systems, 29(2), 51-70. https://doi.org/10.2308/isys-50995

Dutordoir, M., Roosenboom, P., \& Vasconcelos, M. (2014). Synergy disclosures in mergers and acquisitions. International Review of Financial Analysis, 31, 88-100. https://doi.org/10.1016/j.irfa.2013.09.005

Dutta, S., \& Jog, V. (2009). The long-term performance of acquiring firms: A re-examination of an anomaly. Journal of Banking and Finance, 33(8), 1400-1412. https://doi.org/10.1016/j.jbankfin.2009.02.004

Elleuch, S. (2003). L'impact des informations comptables sur les rendements boursiers: étude de trois 
événements sur le marché français [The Impact of Accounting Information on the French Stock Market: An Empirical Study of Three Announcements]. Comptabilité - Contrôle - Audit, 9(2), 137-150. https://doi.org/10.3917/cca.092.0137

Fama, E.F. \& Jensen, M.C. (1983). Separation of Ownership and Control. Journal of Law and Economics, 26(2), 301-325. https://www.jstor.org/stable/725104

Field, L. C., \& Mkrtchyan, A. (2017). The effect of director experience on acquisition performance. Journal of Financial Economics, 123(3), 488-511. https://doi.org/10.1016/j.jfineco.2016.12.001

Goel, A. M., \& Thakor, A. V. (2010). Do Envious CEOs Cause Merger Waves? Review of Financial Studies, 23(2), 487-517. https://doi.org/10.1093/rfs/hhp088

Gorton, G., Kahl, M. \& Rosen, R.J. (2009). Eat or Be Eaten: A Theory of Mergers and Firm Size. The Journal of Finance, 64(3), 1291-1344. https://doi.org/10.1111/j.1540-6261.2009.01465.x

Grinstein, Y., \& Hribar, P. (2004). CEO compensation and incentives: Evidence from M\&A bonuses. Journal of Financial Economics, 73(1), 119-143. https://doi.org/10.1016/j.jfineco.2003.06.002

Gruber, D. A., Smerek, R. E., Thomas-Hunt, M. C., \& James, E. H. (2015). The real-time power of Twitter: Crisis management and leadership in an age of social media. Business Horizons, 58(2), 163-172. https://doi.org/10.1016/j.bushor.2014.10.006

Harford, J. (2003). Takeover bids and target directors' incentives: The impact of a bid on directors' wealth and board seats. Journal of Financial Economics, 69(1), 51-83.

Harford, J., Humphery-Jenner, M., \& Powell, R. (2012). The sources of value destruction in acquisitions by entrenched managers. Journal of Financial Economics, 106(2), 247-261. https://doi.org/10.1016/j.jfineco.2012.05.016

Hayward, M. (2007). Ego check: why executive hubris is wrecking companies and careers and how to avoid the trap. Kaplan Pub.

Iatridis, G. E. (2013). Environmental disclosure quality: Evidence on environmental performance, corporate governance and value relevance. Emerging Markets Review, 14(0), 55-75. http://dx.doi.org/10.1016/j.ememar.2012.11.003

Ismail, A. (2011). Does the Management's Forecast of Merger Synergies Explain the Premium Paid, the Method of Payment, and Merger Motives? Financial Management (Wiley-Blackwell), 40(4), 879-910. https://doi.org/10.1111/j.1755-053X.2011.01165.x

Kane, G. C. (2017). The evolutionary implications of social media for organizational knowledge management. Information and Organization, 27(1), 37-46. https://doi.org/10.1016/j.infoandorg.2017.01.001

Kaplan, A. M. (2011). Twitter ou le pouvoir de 140 caractères. L'Expansion Management Review, 140(1), 104-113. https://doi.org/10.3917/emr.140.0104

Kimbrough, M. D., \& Louis, H. (2011). Voluntary Disclosure to Influence Investor Reactions to Merger Announcements: An Examination of Conference Calls. The Accounting Review, 86(2), 637-667. https://doi.org/10.2308/accr.00000022

Kothari, S. P., Li, X., \& Short, J. E. (2009). The Effect of Disclosures by Management, Analysts, and Business Press on Cost of Capital, Return Volatility, and Analyst Forecasts: A Study Using Content Analysis. The Accounting Review, 84(5), 1639-1670. https://doi.org/10.2308/accr.2009.84.5.1639

Lambert, R., Leuz, C., \& Verrecchia, R. E. (2007). Accounting Information, Disclosure, and the Cost of Capital. Journal of Accounting Research, 45(2), 385-420. https://doi.org/10.2307/4622036

Leuz, C., \& Verrecchia, R. E. (2000). The Economic Consequences of Increased Disclosure. Journal of Accounting Research, 38, 91-124. https://doi.org/10.2307/2672910

Li, L., \& Tong, W. H. S. (2018). Information uncertainty and target valuation in mergers and acquisitions. Journal of Empirical Finance, 45, 84-107. https://doi.org/10.1016/j.jempfin.2017.09.009

Loughran, T. \& Vijh, A.M. (1997). Do Long-Term Shareholders Benefit From Corporate Acquisitions? The Journal of Finance, 52(5), 1765-1790. https://doi.org/10.1111/j.1540-6261.1997.tb02741.x

Martynova, M., \& Renneboog, L. (2009). What determines the financing decision in corporate takeovers: Cost of capital, agency problems, or the means of payment? Journal of Corporate Finance, 15(3), 290-315. https://doi.org/10.1016/j.jcorpfin.2008.12.004 
Mazboudi, M., \& Khalil, S. (2017). The attenuation effect of social media: Evidence from acquisitions by large firms. Journal of Financial Stability, 28, 115-124. https://doi.org/10.1016/j.jfs.2016.11.010

Nisar, T. M., Prabhakar, G., \& Strakova, L. (2019). Social media information benefits, knowledge management and smart organizations. Journal of Business Research, 94, 264-272. https://doi.org/10.1016/j.jbusres.2018.05.005

Oler, D. K., Harrison, J. S., \& Allen, M. R. (2008). The danger of misinterpreting short-window event study findings in strategic management research: An empirical illustration using horizontal acquisitions. Strategic Organization, 6(2), 151-184. https://doi.org/10.1177/1476127008090008

Paniagua, J., \& Sapena, J. (2014). Business performance and social media: Love or hate? Business Horizons, 57(6), 719-728. https://doi.org/10.1016/j.bushor.2014.07.005

Parveen, F., Jaafar, N. I., \& Ainin, S. (2015). Social media usage and organizational performance: Reflections of Malaysian social media managers. Telematics and Informatics, 32(1), 67-78. https://doi.org/10.1016/j.tele.2014.03.001

Povel, P., \& Singh, R. (2006). Takeover Contests with Asymmetric Bidders. The Review of Financial Studies, 19(4), 1399-1431. https://doi.org/10.1093/rfs/hhj034

Rau, R. P., \& Vermaelen, T. (1998). Glamour, value and the post-acquisition performance of acquiring firms. Journal of Financial Economics, 49(2), 223-253. https://doi.org/10.1016/s0304-405x(98)00023-3

Renneboog, L., \& Zhao, Y. (2014). Director networks and takeovers. Journal of Corporate Finance, 28, 218-234. https://doi.org/10.1016/j.jcorpfin.2013.11.012

Roll, R. (1986). The Hubris Hypothesis of Corporate Takeovers. The Journal of Business, 59(2), 197-216.

Securities Exchange Commission (SEC). (2013). Press Release 2013-51: SEC says social media OK for company announcements if investors are alerted. Retrieved from https://www.sec.gov/news/press-release/2013-2013-51htm

Shenoy, J. (2012). An examination of the efficiency, foreclosure, and collusion rationales for vertical takeovers. Management Science, 58(8), 1482-1501. https://doi.org/10.1287/mnsc.1110.1498

Shih, Y. C., \& Hsu, B. J. (2009). Does stock misvaluation differentiate the motives for takeovers? Review of Pacific Basin Financial Markets and Policies, 12(3), 545-566. https://doi.org/10.1142/S0219091509001745

Shim, J. (2011). Efficiency Changes Around Mergers in the U.S. Property-Liability Insurance Industry: A Data Envelopment Analysis. Journal of Business \& Economic Studies, 17(2), 77-96. Retrieved from https://search.ebscohost.com/login.aspx?direct=true \&db=bth\&AN=67519474\&lang=fr\&site=eds-live

Siougle, G., Spyrou, S. I., \& Tsekrekos, A. E. (2014). Conference calls around merger and acquisition announcements: Do they reduce information asymmetry? UK Evidence. Research in International Business and Finance, 30, 148-172. https://doi.org/10.1016/j.ribaf.2013.07.003

Smith, M., \& Taffler, R. J. (2000). The chairman's statement - A content analysis of discretionary narrative disclosures. Accounting, Auditing \& Accountability Journal, 13(5), 624-647. https://doi.org/10.1108/09513570010353738

Tajudeen, F. P., Jaafar, N. I., \& Ainin, S. (2018). Understanding the impact of social media usage among organizations. Information \& Management, 55(3), 308-321. https://doi.org/10.1016/j.im.2017.08.004

Usman, M., Zhang, J., Farooq, M. U., Makki, M. A. M., \& Dong, N. (2018). Female directors and CEO power. Economics Letters, 165, 44-47. https://doi.org/10.1016/j.econlet.2018.01.030

Yu, Y., Duan, W., \& Cao, Q. (2013). The impact of social and conventional media on firm equity value: A sentiment analysis approach. Decision Support Systems, 55(4), 919-926. https://doi.org/10.1016/j.dss.2012.12.028

Zhang, J. (2015). Voluntary information disclosure on social media. Decision Support Systems, 73, 28-36. https://doi.org/10.1016/j.dss.2015.02.018

Zhou, M., Lei, L., Wang, J., Fan, W., \& Wang, A. G. (2015). Social Media Adoption and Corporate Disclosure. Journal of Information Systems, 29(2), 23-50. https://doi.org/10.2308/isys-50961

Zollo, M., \& Meier, D. (2008). What Is M\&A Performance? Academy of Management Perspectives, 22(3), 55-77. https://doi.org/10.5465/AMP.2008.34587995 
Zollo, M., \& Singh, H. (2004). Deliberate learning in corporate acquisitions: Post-acquisition strategies and integration capability in U.S. bank mergers. Strategic Management Journal, 25(13), 1233-1256. https://doi.org/ https://doi.org/10.1002/smj.426

\section{Copyrights}

Copyright for this article is retained by the author(s), with first publication rights granted to the journal.

This is an open-access article distributed under the terms and conditions of the Creative Commons Attribution license (http://creativecommons.org/licenses/by/4.0/). 